\title{
Status and trends of the Canada Goose Branta canadensis in France
}

\author{
Tillstånd och utveckling för kanadagåsen Branta canadensis i Frankrike
}

CAROL FOUQUE \& VINCENT SCHRICKE

\begin{abstract}
An enquiry to determine the distribution and abundance of the Canada Goose Branta candensis in France was undertaken in 2008. Responses were received from 92 out of the 96 departments. Canada Geese were reported in 56 of the 92 departments, in 8 of which the species had only appeared after 2000 . For half of the 56 departments, the species was observed only in summer. Canada Geese summered in 38 departments, numbering at least 4250 birds. At least 6000 birds are also thought to winter in France as of 2008/2009, when the species is more widespread. Winter numbers are increasing exponentially. In 5 departments, crop damage and public health issues

have resulted in local management measures in the last 3 years (e.g. egg pricking and culling of adults). We discuss the need for further regulation and legislation in the light of these conflicts and hybridisation with other species.

Carol Fouque, Office National de la Chasse et de la Faune Sauvage, CNERA Avifaune migratrice, Station de la Dombes, 01330 Birieux, France

Vincent Schricke, Office National de la Chasse et de la Faune Sauvage, CNERA Avifaune migratrice, 39, Bd Albert Einstein, CS 42355, 44323 Nantes Cedex 3, France E-mail: vincent.schricke@oncfs.gouv.fr
\end{abstract}

Received 23 March 2011, Accepted 29 August 2011, Editor : S. Svensson

\section{Introduction}

The Canada Goose Branta canadensis originates from the United States and Canada, but has been widely released in Europe since the 17th century, since when it has also escaped from zoos and private collections (Rehfisch et al. 2000). They were first released in Great Britain for ornamental purposes but also for wildfowl collections, food and hunting. At the beginning of the 20th century, Canada Geese were still released in Europe for hunting purposes, for example in Scandinavia. Breeding outside private collections was rare before the 19th century, but later became common in Europe.

In UK, after the second war, some regulation was needed because of the agricultural damage (destruction of eggs and individuals; relocation of adults caught during moulting). However, the effect of the latter effort was only to further disperse and increase the populations (Holloway 1996). Experts believe that the rapid increase began in the 1970s and 1980s when birds gathering in excessive numbers in parks and lakes were removed from there and released in the wild. Thus, councils and park keepers were unwittingly helping to spread their numbers (Syal 2009). The numbers have increased by a factor of five since the late 1960s (Rehfisch et al. 2000). In 1999, the UK held more than 2300 breeding pairs and the wintering population was probably about 80,000 (Dubois et al. 2007). With $8 \%$ increase per year, the number of Canada geese in Britain was expected to have risen to more than 200,000 by 2010 (Blair et al. 2000). In Belgium, the first observations were made in 1950-1960 (Lippens \& Wille 1972) where the species first bred in the wild in 1973. In Flanders, there were 2700 wintering individuals in 1997 and nearly 10,000 individuals in 2004 (Anselin \& Devos 2005). This species is also present in Denmark, Switzerland, Germany and Holland. The European population was estimated at about 160,000 individuals at the end of the 2000s (Dubois et al. 2007).

Most introductions of non-native species have occurred in Western Europe (Wright 2008, Hulme et al. 2009). The impact of alien species in Europe is close to 10 billion euros annually and this figure is an underestimate as potential economic and environmental impacts are unknown for almost $90 \%$ of these species (Hulme et al. 2009). The DAISIE project (Delivering Alien Invasive Species Inven- 
tories for Europe; www.europe-aliens.org), lists 100 alien invasive species which pose an environmental, human health, social or economical threat to society, including the Ruddy Duck Oxyura jamaicensis, the African Sacred Ibis Threskiornis aethiopicus, and the Canada Goose of particular concern in France (Vilà et al. 2009). Canada Goose lies in second place amongst the top-ten invasive DAISIE species with the highest number of different impact types on ecosystem services in Europe, with four categories of impact types.

Canada Geese can be hunted under the Birds Directive (1979; Annexe II/1: hunting species) but this is not permitted under the Berne Convention (1979; Annexe III : protected species with regulation of hunting) and the Bonn Convention (1979; Annexe II: bad status with adapted measures for management).

Most of the introductions of Canada Geese in France were made between 1960 and 1970 for ornamental purpose. During1970-1980, further birds escaped from private properties and parks. In addition, hunters released birds into the wild to enhance future hunting opportunities. This favoured the establishment of feral populations in several part of the country (Pascal \& Clergeau 2003). This French population is mostly sedentary, but the population increases in winters when birds from Scandinavia and the UK come to France. Some movements can be observed between feeding and resting sites but no moult migrations have been reported as in the UK. In the 1990s the French population was estimated at about 700 individuals. In France the Canada Goose is an exotic but protected species as all the other wild species of Branta genus (national list of protected species 1970: articles 1 and 5 revised by the ministry policy from the 17-04-1981). This legislation, which does not distinguish introduced individuals from wild ones, does not allow destruction of eggs or adults, catching, selling or buying, or transporting individuals, alive or dead. As the need for regulation has been rising during the last five years in places where damage occurs, this article attempts to make an up-dated synthesis about this species at the national level.

\section{Study area, material and methods}

To update the status and distribution of the Canada Goose in France, a national enquiry was undertaken in 2008, using the national network of observers working on Waterfowl and Wetlands. This study was made by the French Hunting and Wildlife Agency (ONCFS) with the help of the na- tional and local hunting associations (Fédérations départementales des chasseurs). Ninety-two responses were received from the total of 96 departments. The majority of the answers came from the environmental wardens of ONCFS $(n=58)$ or from technicians in departmental hunting organisations $(n=19)$. Other organisations provided information on this species in 7 departments.

Data were collected at the level of local authority districts but collated at the department level or at the scale of $10 \mathrm{~km}$ squares, a European standard georeferenced grid.

\section{Results}

Decade of first observation and origin of the birds The decade of the first observation of the Canada Goose in nature was known for 31 of the 58 departments (Figure 1): one department in the 1960s, 6 departments in the 1970s and 9 departments in the 1990s. In the 2000s it appeared in 9 new departments, confirming the ongoing expansion. These 9 departments were located outside the centre of France. Old populations in 7 departments that were also located outside the centre of France and had the highest densities didn't grow up until 2000.

The origin of the geese was known from 26 departments (Figure 2). In five cases they had escaped from ornithological parks but in more than half of the cases $(n=17)$, they had escaped from private properties or were released into the wild for hunting purposes. In one department, the birds could have come from neighbouring Belgium. Whatever the situation, we are dealing with a feral populations well adapted to their environment.

\section{Numbers, distribution and trends in winter population}

Winter numbers were known for 54 of the 57 departments where the species was present (Figure $3)$. The numbers differed between the departments: $45 \%$ of them had less than 10 individuals, 7 had between 100 and 200, and 10 departments had more than 200, these highest densities being located in the centre of France. The French population could be estimated at about 6000 individuals in the winter 2008/2009.

The spatial distribution within each of the 54 departments differed: the majority of them $(n=41$, $73 \%$ ) had 5 or less $10 \mathrm{~km}$ squares occupied by the species, being located in few sites. In these departments, it was still possible to prevent the expansion of the species further while in 10 other departments, 
Figur 1 : Decade of first observations

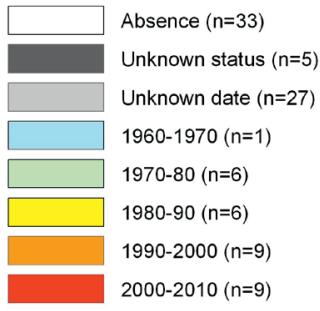

Figure 1. The decade when the Canada Goose was first recorded in the departments.

Decenniet då kanadagåsen registrerades för första gången i departementen.
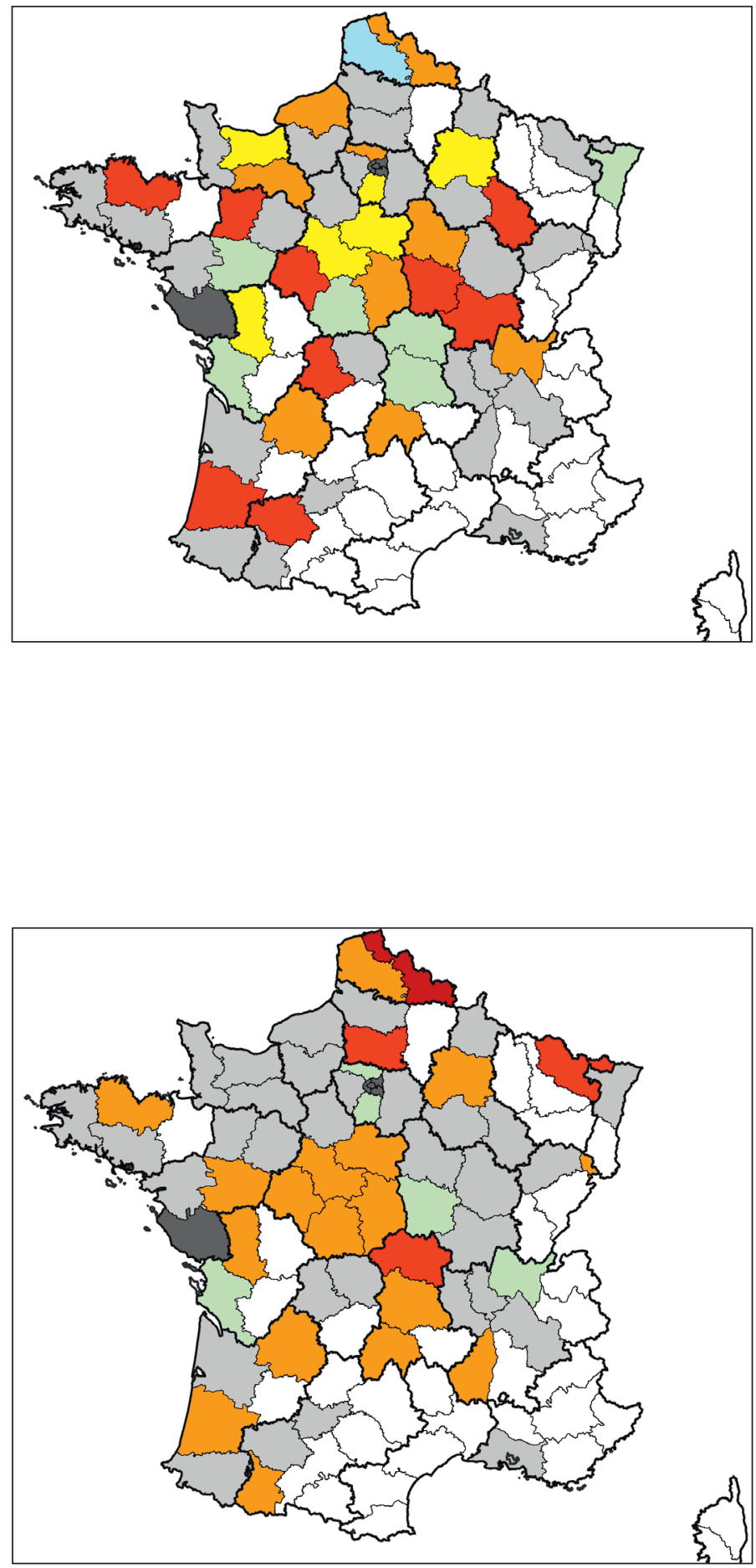

Figure 2. The origin of the Canada Geese in the different departments. Ursprunget för kanadagässen $i$ de olika departementen.
Absence $(n=33)$

Unknown status $(\mathrm{n}=5)$

Unknown origin $(n=32)$

Parkland $(n=5)$

Private properties $(n=17)$

Parkland + private properties $(n=3)$

Abroad origin $(n=1)$ 


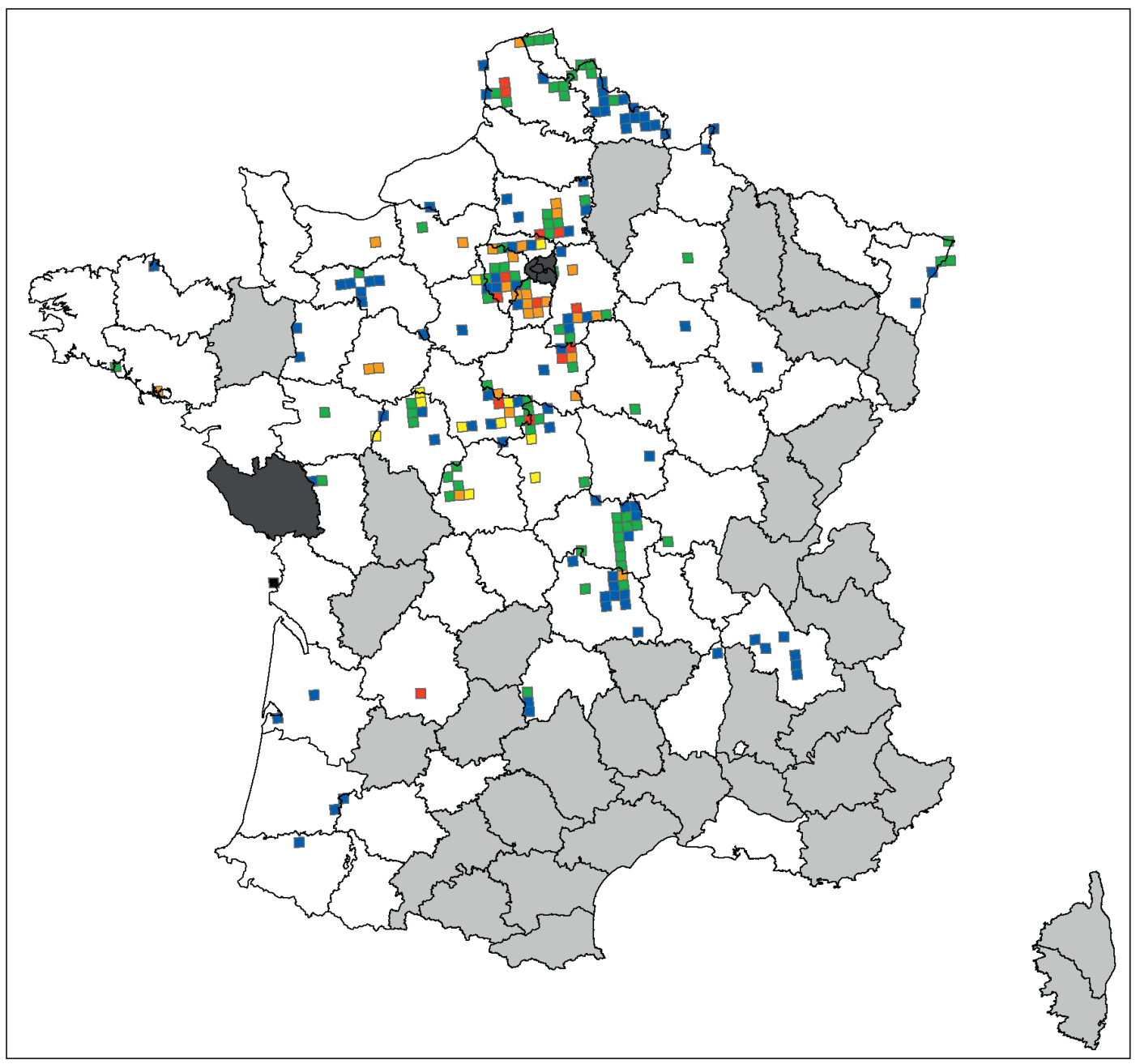

Absence $(n=34)$

Unknown status $(n=5)$

Presence $(n=57)$

Absence in $2008(n=11)$

$1-10$ individuals $(n=93)$

$11-50$ individuals $(n=68)$

$51-100$ individuals $(n=27)$

$101-200$ individuals $(n=13)$

$>200$ individuals $(n=1)$
Figure 3. Winter distribution of the Canada Goose in the departments (presence/absence) and in $10 \mathrm{~km}$ squares (colour code for numbers).

Kanadagåsens vinterförekomst $i$ departementen (finns/saknas) och i $10 \mathrm{~km}$ rutort (färgkod för antal). 
the species seemed to be already very widespread.

About half of the 202 occupied $10 \mathrm{~km}$ squares had less than 10 individuals in winter. Nearly all of the squares with the highest numbers (50-200 individuals) were located in the centre of France. One square held more than 200 birds, located on an island on the Atlantic coast.

The winter population has shown an exponential increase (Dubois et al. 2007, Deceunink et al. 2009), with a rapid change after 2005 when about 3000 birds were recorded. Three years later, the population had doubled (6000 individuals in winter 2008/2009).

\section{Numbers, distribution and trends in summer non- breeding and breeding population}

In summer, the species was observed in 39 departments, 18 less than in winter. The population seemed less widespread in summer than in winter. Summer distribution and minimum size of the Canada Goose population was known for the 39 departments. $45 \%$ of these had between 10 and 50 individuals (against $45 \%$ under 10 individuals in winter), mostly in central France, where 5 departments had more than 200 individuals (against 10 in winter) and 6 other ones had between 100 and 200 (same as in winter). The population was more evenly distributed between departments in summer than in winter. The minimum French summer population could be estimated at about 4250 individuals, which was 1500 below the number found in winter.

The breeding population of Canada Goose was not as large as the summer population because birds reproduce only when they are 3 years or older. The number of breeding pairs in 2006 was estimated by Wetlands International France to be between 200 to 250 in 35 departments (Dubois et al. 2007).

In 2008 , the breeding population was distributed between 39 departments, with the same distribution as the non-breeding summer population: where there were summer observations of Canada Goose there were breeding pairs. The total number of breeding pairs in France was estimated at about 1100 in 2008. It was four times more than in 2006 but in 2006 the population was underestimated as no specific enquiry was made. The total number of communes occupied by the species in France was about 294 and quantitative data were known for $97 \%$ of them.

The breeding population was observed in 199 squares (Figure 4), against 212 in winter. 149 occupied squares had less than 5 breeding pairs and the highest densities per square were between 5 and 20 pairs. These squares were not all located in the centre of France as they were widespread all over the country, except the four squares which held more than 20 pairs.

\section{Trends in annual numbers}

Trends in annual numbers (winter and summer population) were known in 44 of the 58 occupied departments (Figure 5). Populations had been increasing in 28 departments while populations were stable in 16 other ones. For example, the expansion of the populations from the centre of France to all the Loire river areas was obvious.

\section{Impacts of the species}

The impacts of the Canada Goose, an herbivore species, on the natural ecosystem (vegetation belt of the water bodies) has not been studied in France but are frequently reported anecdotally.

In France, impacts of the species were identified in 31 of the 58 departments with annual presence. Several types of conflict were identified. The most important one was the damage on fields with young wheat and maize and on permanent hay meadows. This occurred in the centre of France with the highest goose densities. Problems linked to their feeding on the greens of golf courses were also mentioned. In one department, there was a public health problem in a leisure park associated with the abundance of dropping (feaces), considered responsible for eutrophication of water and the source of potential diseases. Other types of problems were due to adverse interactions with other species: laying eggs in nests of other geese, food and spatial competition with Mute Swan Cygnus olor, other species of geese and rails (Rallidae). In four departments, far away from each other, hybrids with Greylag Goose Anser anser were observed, suggesting a major risk of genetic introgression to the latter species.

When Canada Geese fed in hay meadows, the damage by intensive grazing was estimated to constitue a loss of $50 \%$ of the production of hay bales. One example comes from the Loing valley in the centre of France. There were no Canada Geese in 2004 and the production of one plot of meadows was 1000 hay bales. In 2005, with the grazing of 50 Canada Geese in the same plot, only 750 hay bales were produced, and in 2006 there were 80 geese and only 350 hay bales. 


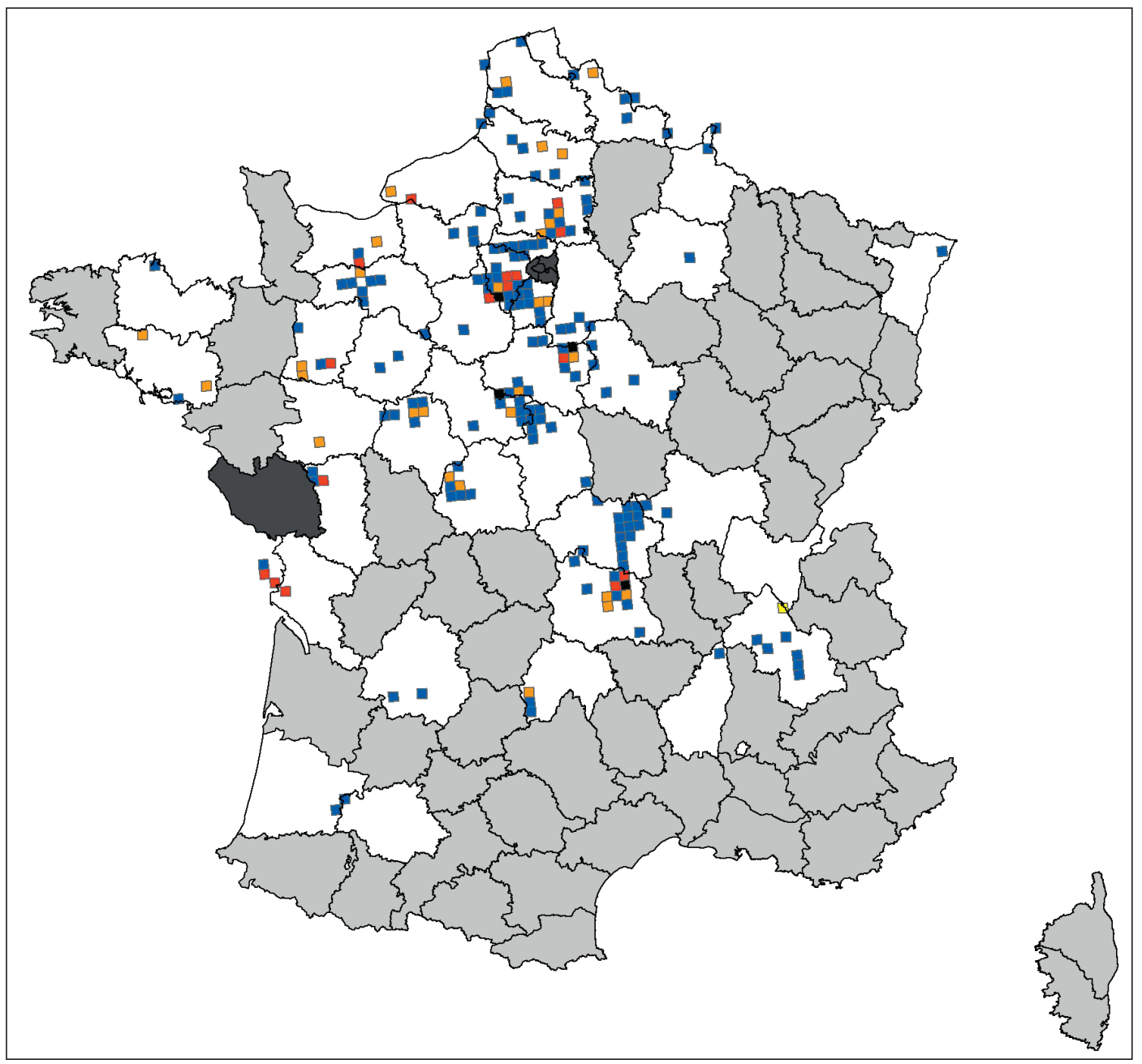

Absence $(n=52)$

Unknown status $(n=5)$

Presence $(n=39)$

Absence in $2008(n=1)$

1-5 pairs $(n=149)$

6-10 pairs $(n=29)$

11-20 pairs $(n=16)$

$>20$ pairs $(n=4)$
Figure 4. Number of breeding pairs of Canada Geese in the departments (presence/absence) and in $10 \mathrm{~km}$ squares (colour code for numbers).

Antal häckande par av kanadagås i departementen (finns/ saknas) och i $10 \mathrm{~km}$ rutor (färgkod för antal). 

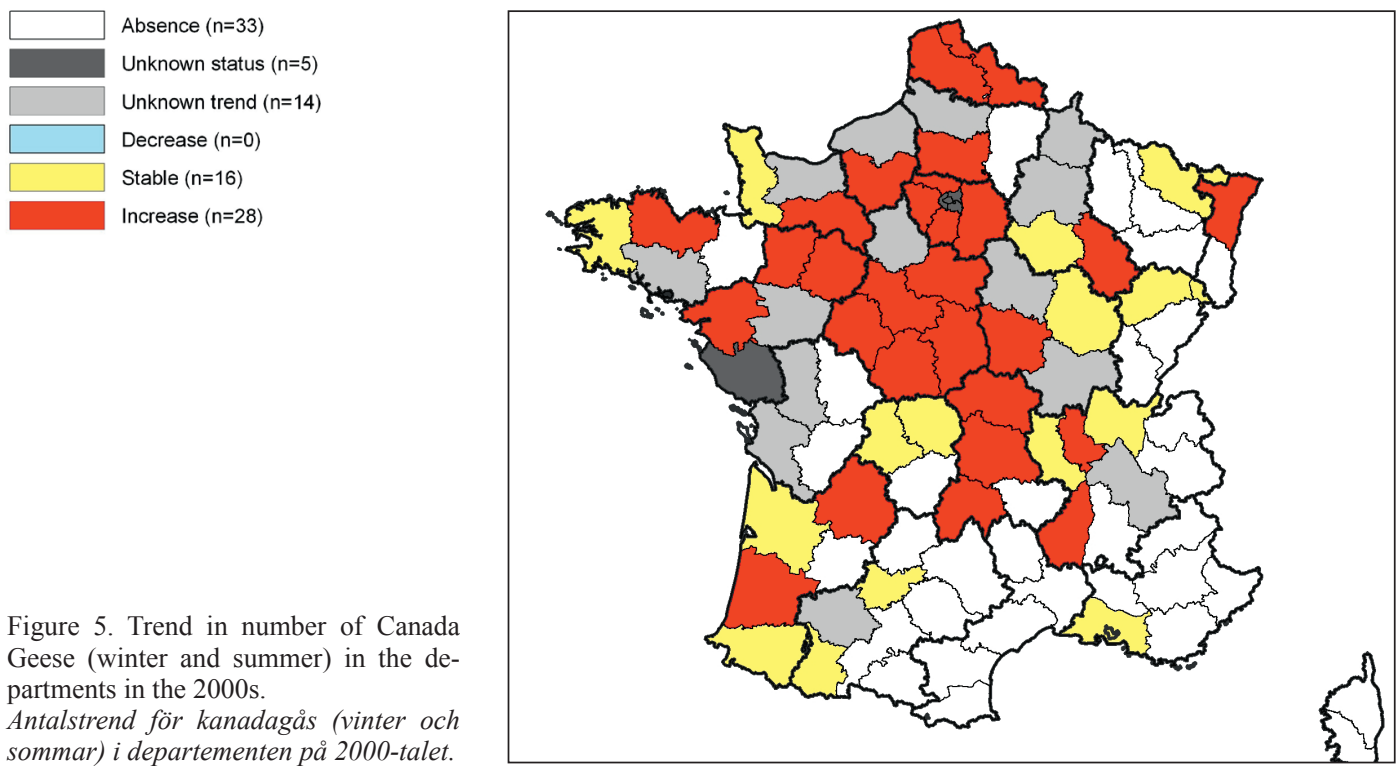

Figure 5. Trend in number of Canada Geese (winter and summer) in the departments in the 2000s.

Antalstrend för kanadagås (vinter och sommar) i departementen på 2000-talet.

\section{Measures of regulation}

Regulation of the total Canada Goose population is not easy because of its protected status. However, it is possible to regulate the species on private land according to French Law. Wardens of ONCFS were responsible for these measures of regulation. So, during recent years, regulation measures have been implemented in France in several departments where there was damage to crops: since 2005 in one department in northern France, since 2007 in three departments in the centre, and in one more department in 2008. Three other departments could be concerned in 2009 .

In these four departments, three methods of regulation were applied: shooting of adults and subadults, culling of eggs and, in one department, they were captured with a net and killed. The results linked to the regulation showed no strong effect on the populations. In one department where reproductive control was combined with an increase in adult mortality, the results were good as the population decreased dramatically but regulation was stopped before the population had been eradicated. The regulation in this department was a success because the birds were not able to escape far away when they were disturbed. In other departments where regulation started with the same methods, the number of birds did not decrease at the scale of the department because the geese moved to other sites within the department.

\section{Discussion}

The difference between the winter (6000 individuals) and summer (4250 individuals) populations could be explained by several hundred birds which arrive to overwinter amongst the resident stock, mostly from Fennoscandia or perhaps from Britain, although no British ringing recoveries have been reported (Blair et al. 2000). But this difference is so high that it could also strongly suggests an underestimation of the summer population. The population is more difficult to estimate in summer than in winter because the tall vegetation around water bodies and also because the individuals were less aggregated in summer.

The problems caused by the increase in the nonnative Canada Goose population are associated with the impacts it has on biodiversity and humans (Hugues et al. 1999). The Canada Goose is an herbivore that eats flowers, leaves, stalks and roots but also seeds and berries. The birds have considerable energy requirements and can spend more than 12 hours a day for feeding (Cramp \& Simmons 1977). They feed in terrestrial habitats and 
like cereal fields (wheat and barley), colza (rape) fields and grass meadows. They also feed on the vegetation around water bodies and on the golf courses where there is short vegetation. Because they are gregarious, Canada Geese may destroy cultivated vegetation when walking and make some meadows or fields unproductive because of their droppings (Cramp \& Simmons 1977). Impact on humans could be separated in two subcategories, economic or aesthetic. Collisions between airplanes and Canada Geese are responsible for 88 crashed planes and 243 human deaths at Heathrow in England (Syal 2009). Collisions between aircraft and birds cost the world civil aviation industry around 200,000 euros per year (Syal 2009). The high densities associated with leisure water bodies have been held responsible for the degradation of water quality (contribution to water eutrophication by their faeces). This species could be a disease vector and a public health risk. The greens of golf courses could be destroyed by grazing Canada Geese. Problems regarding hybridisation (individual level) and competition are thought to be minor despite much speculation, especially with regard to competition (Allan et al. 1995). Fabricius et al. (1974) documented considerable aggression between Canada Geese and Greylag Geese when nesting together on islands off the Swedish coast, but found no evidence of negative effects on the numbers of breeding pairs of either species. Master \& Oplinger (1984), on the other hand, suggested that Mallard Anas plathyrhynchos productivity in the eastern United States may be negatively affected by increasing nesting densities of Canada Geese (Hughes et al. 1999).

Canada Geese tends to dominate wetland avian ecosystems (Rehfisch et al. 2000). This species could be aggressive with other smaller waterfowl (ducks) (Cramp \& Simmons 1977). Space and feeding competition have been observed in UK where the densities were high (Gibbons et al. 1993). They can be aggressive in nest defence. They are known to kill ducks, Moorhen and Coot. When moving, Canada Geese could destroy eggs of fish or frogs.

Eradication of alien species is a key conservation tool to mitigate the impacts caused by biological invasions (Genovesi \& Shine 2003, Genovesi 2005). The Convention on Biological Diversity considers eradication as the best alternative when prevention fails.

In England, Kirby and colleagues tried to model the dynamics of the population to find the important factors to consider for the regulation (Hughes et al. 1999). The theory was that the rate of popu- lation growth should decrease more rapidly when removing adults than nests, due to the high adult and juvenile survival of this long-lived bird. Moreover, 20 years is required to reduce the population from 100 to 10 with removal of $20 \%$ of the adults and $70 \%$ of the nests. The experience in the field in England brought a strong revelation. With an adult survival reduced to about 35-40\% (obtained by regulation), the population will still continue to growth with $8 \%$ per year. This species has combines the advantages of longevity with high fecundity (producing 5 or 6 young each year). Effective regulation of the species depends on the nature of the site, the type of damage occurring and on the population biology of the local birds. In a given site, if there is suitable feeding habitat as grazing pasture or cereal fields, density-dependent factors are unlikely to act to regulate population size before high numbers of birds are present.

The cost of the impacts of alien invasive species over the world is estimated to $240 \$$ per year and per person (Mazaubert 2008). The monetary cost of the Canada Goose in Germany due to eutrophication is 1.02 million of euros per year (Gebhart 1996 in Vilà et al. 2009).

In Holland, before 2009, Canada Geese were not subject to regulation (compensation was paid for grey geese). In UK, destruction of eggs gave good results because the birds were aggregated around water bodies. In Belgium, the species was put on the list of hunting species since July 2008 while all the other geese has been protected since 1981 (Kuijcken, unpublished data). In this last country, a national hunting plan was launched but it produced a spreading of the population and pushed them in protected places. The situation in countries as New Zealand, England or Finland showed that impacts of Canada Geese cost a lot when the population start to spread. As effective regulation is expensive in money and time, regulation is most efficient if rapid and undertaken before the spread of the species.

In France, it seems that regulation measures taken until now were not efficient. In fact, it is know that density-dependent factors are acting to regulate population size only at long established breeding sites and natal-site fidelity prevents most of the non-breeding adults from moving away to establish new colonies elsewhere (Allan et al. 1995). So it could be better to leave geese at these old established sites with the same numbers of birds, to not kill non-breeding adult and to concentrate in other newly-established breeding sites where the carrying capacity will be reached for ten or more years. 
Another possible solution would be to launch a national action plan to eradicate the species with an integrated management strategy (albeit with methods adapted to each site) but it would be efficient only with the collaboration of the neighbouring countries, since recolonisation from outside would be likely. If the species would be regulated only in France, the task would be prolonged and inefficient. The only solution is total eradication of the species in Europe where it is not native.

\section{Acknowledgements}

One thousand observers from the French network "Waterfowl and Wetlands" have carried out the fieldwork. We would like to thank all of them for their efforts, which allowed the production of such a collective synthesis at the national scale. They are from ONCFS (at the regional and departmental levels and at the research and study direction) and from departmental hunting federations. We also acknowledge the help of Patricia Vincent for data computerization.

\section{References}

Anselin, A. \& Devos, K. 2005. Wintertellingen van verwilderde ganzen in Vlaaderen, met bijzondere aadacht voor de Canadese Gans Branta candensis. Natuur Oriolus 71: 90-102.

Allan, J.R., Kirby, J.S. \& Feare, C.J. 1995. The biology of Canada Geese Branta canadensis in relation to the management of feral population. Wildlife Biology 1(3): 129142.

Blair, M.J., Mckay, H., Musgrove, A.J. \& Rehfisch, M.M. 2000. Review of the status of introduced non-native waterbird species in agreement area of the African-Eurasian Waterbird Agreement research contract CR0219. BTO Research Report 229: 1-129.

Cramp, S. \& Simmons, K.E.L. 1977. Handbook of the Birds of Europe the Middle East and North Africa, the Birds of Western Paleartic, volume 1 Ostrich to Ducks. Oxford University Press, Oxford.

DAISIE European Invasive Alien Species Gateway. 2008. Available from: http://www.europe-aliens.org/

Deceunink, B. \& Maillet, N. 2009. Dénombrements d'Anatidés et foulques hivernant en France - JANVIER 2008. http://www.lpo.fr/etudes/wetlands/anatides_hivernant/index.shtml

Dubois, P.J. 2007 Les oiseaux allochtones en France : statut et interactions avec les espèces indigènes. Ornithos 14-6: 329-364.

Fabricius, E., Bylin, A. \& Radesäter, T. 1974. Intra- and interspecific territorialis minmixed colonies of the Canada Goose Branta canadensis and the Greylag Goose Anser anser. Ornis Scandinavica 5: 25-35.

Genovesi, P. \& Shine, C. 2003. Convention relative à la conservation de la vie sauvage et du milieu naturel de
1'Europe: Stratégie européenne relative aux espèces exotiques envahissantes. Conseil de l'Europe, T-PVS (2003) 7: $1-50$.

Genovesi, P. 2005 Eradications of invasive alien species in Europe: a review. Biological Invasions 7: 127-133.

Gibbons, D.W., Reid, J.B. \& Chapman, R.A. 1993 The new atlas of breeding birds in Britain and Ireland: 1988 -1991. London. Poyser.

Holloway, S. 1996. The historical atlas of breeding birds in Britain and Ireland 1875-1900. T \& AD Poyser, London.

Hughes, B., Kirby, J. \& Rowcliffe, J.M. 1999. Waterbird conflicts in Britain and Ireland: ruddy ducks Oxyura jamaicensis, Canada Geese Branta candensis, and Cormorants Phalacorocorax carbo. Wildfowl 50: 77-99.

Hulme, P.E., Pysek, P., Nentwig, W. \& Vila, M. 2009. Will threat of biological invasions unite the European Union? Science 324: 40-41.

Lippens, L. \& Wille, H. 1972. Atlas des oiseaux de Belgique et d'Europe occidentale. Tielt, Belgium. Lannoo.

Master, T.L. \& Oplinger, C.S. 1984 Nesting and brood rearing ecology of an urban waterfowl population (Anas platyrhynchos and Branta canadensis) in Allentown Pennsylvania. Proceedings of the Pennsylvania Academy of Science 58: 175-180.

Mazaubert, E. 2008. Les espèces exotiques envahissantes en France: évaluation des risques en relation avec l'application de la Directive cadre sur l'eau. Rapport de stage Master 2 professionnel, Bordeaux, CEMAGREF: $125 \mathrm{p}$.

Pascal, M. \& Clergeau, Ph. 2003. La Bernache du Canada Branta c. canadensis. In: Invasions biologiques et extinctions. 11000 d'histoire des vertébrés en France. (Pascal, M., Lorvelec, O. \& Vigne, J.D., ed.) Quae-Belin Editions.

Rehfisch,, M., Blair, M. \& McKay, H. 2000. No passport? introducing the introduced. BTO News 229: 6-7.

Syal, R. 2009. Call for airport cull of Canada geese: a growing population of 10,000 birds near Heathrow has sparked fears of a new crash like that in the Hudson river. The Observer, Sunday 25 January 2009.

Wright, L. 2008. Watch out for weird waterbirds! BTO News 5: $13-15$

Vilà, M., Basnou, C., Pyšek, P., Josefsson, M., Genovesi, P., Gollasch, S., Nentwig, W., Olenin, S., Roques, A., Roy, D., Hulme, Ph.E. \& DAISIE partners 2009. How well do we understand the impacts of alien species on 5 ecosystem services? A pan-European cross-taxa assessment. Frontiers in Ecology and the Environment.

\section{Sammanfattning}

I Frankrike gjordes en riksomfattande enkät 2008 för att kartlägga kanadagåsens spridning och förekomst. Rapporteringen skedde dels på departementsnivå och dels för rutor om 10 gånger 10 kilometer. Resultatet redovisas i Figur 1-5.

De flesta introduktioner skedde åren 1960-1970 som prydnadsfåglar i parker. Under perioden 1970-1980 rymde fåglar från parker och fågelsamlingar och andra planterades ut för jaktändamål. Detta ledde till etableringen av viltlevande bestånd 
på flera håll i landet. Dessa fåglar är i huvudsak stannfåglar. Vintertid har sedan också tillkommit fåglar från norra Europa.

Beståndet hade vuxit till 700 individer på 1990-talet. Vintern 2008/2009 var beståndet 6000 fåglar. Under häckningstiden 2008 registrerades 4250 individer, vilket är klart lägre än vinterbeståndet. Skillnaden bedöms som för stor för att kunna förklaras av övervintrande fåglar norrifrån och antyder därför att det häckande beståndet underskat- tades. Beståndet bedöms vara under fortsatt ökning i de flesta departement.

En del åtgärder för att förhindra spridning av kanadagåsen för att reducera olika typer av skadegörelse har vidtagits. Åtgärderna har dock inte varit framgångsrika och torde heller inte bli det om de bara genomförs i Frankrike. Då kommer återkolonisation att ske från grannländerna. Enda sättet att bli av med kanadagåsen är en samordnad utrotning av den i hela Europa. 